\title{
Improvement of Service Quality and Store Image to Retain Customer in Denpasar
}

\author{
Pande Gde Bagus Naya Primananda \\ Doctor Candidate Marketing Management, Universitas Udayana, Bali, Indonesia \\ pandemagina@gmail.com
}

\begin{abstract}
The study explains about the relationship of service quality and store image with customer satisfaction and loyalty. This research was conducted in hypermarket in Denpasar, Bali. The number of samples in this study was 100 respondents by using purposive sampling technique. Methods of data collection in this study using questionnaires and interviews. The study only use four variables are service quality, store image, customer satisfaction, and customer loyalty. Need to add another variable like repeat purchase, word of mouth positive, trust, marketing mix, or other related variables. There is negative relationship between service quality and loyalty, and negative relationship between store image and customer satisfaction. The theoretical implication is that there is no significant influence between service quality, loyalty, and store image with satisfaction. The practical implications of this study, managers should examine the policies that can be attributed to the findings.
\end{abstract}

Keywords: Service Quality, Store Image

\section{INTRODUCTION}

The development of retail business in recent years is considered increasingly rapid. Along with the rapid development of shopping centers in major cities, modern retail business with Hypermarket, Minimarket, and Supermarket formats is increasingly being established and attracting visitors. In fact, the retail business not only grows in the city center but also grows in the suburbs due to the many settlements in the region, the dynamics of the market and the basis of demand and consumer needs. Currently, there are phenomena that cause changes in the retail world of Indonesia, including traditional retail changes to modern retailers, expansion of foreign retailers, and changes in the function of shopping areas that are not just a place to shop but to be a place of entertainment and socializing.

Parasuraman, et al (1990), defines the service quality as a comparison between the perceived service consumers with the service quality consumers expect. Service quality, as perceived by consumers, can be defined as how far the difference between the expectations or desires of consumers with perceived perception, for the service they receive. If the service received is suitable or even exceeds what the consumer expects, the service quality is perceived as good and satisfactory and if it exceeds the expectation of the consumer, the service quality is perceived as ideal. If the services received are lower than expected, then the service quality is considered poor. 
According to Bloemer and Schroder (2002): "An interesting example how a department store can be used its retail mix to create a store that is attractive to its target market". A company can be seen through its image either positive image or negative image. A positive image can have a good impact on the company; of course, a good image can increase the number of transactions and customer loyalty. Meanwhile, the bad image can make the company suffered losses such as the number of transactions that decreased or viewed negatively by the community. Therefore, service companies that have a good image because it can lead to customer loyalty and can bring a good reputation for the community

Customer satisfaction by Kotler et al. (Tjiptono, 2008: 169) is the level of one's feelings after comparing the performance they perceive as compared to their expectations. According to Kotler and Keller (2009), satisfaction is a feeling of pleasure or disappointment resulting from the comparison of product performance to their expectations. If performance does not meet expectations, then the customer becomes dissatisfied. If performance meets expectations, then the customer is satisfied. If performance exceeds expectations, then customers feel very satisfied.

Chodzaza's research (2013) concluded that service quality has a significant relationship with customer satisfaction and has an impact on customer loyalty. This study also concluded that large consumers are less loyal than small consumers are. According Mellisa (2010) say with a positive store image and good retail services, the company will be able to satisfy its customers. Furthermore, the creation of satisfaction will be able to create customer loyalty to the company as an evaluation of the value of the performance of the store image and retail services that are applied.

The problem in this research is the presence of complaints that appear on the service quality and store image in this company. Although not every company wants a complaint to its customers, the company wants its customers to be satisfied. Complaints that come cannot be regarded as a problem but rather constructive criticism for the company. Therefore, the company should pay more attention in order to reduce the number of existing customer complaints because customer complaints can result in decreased customer loyalty that would be bad for the company.

So the purpose of this study is Improve the service quality and store image, will increase customer loyalty.

\section{HYPHOTHESIS AND METHOD}

The influence of service quality and satisfaction

Prayoga's research (2012) discovers that the service quality has a positive and significant impact on customer satisfaction Ramayana Department Store Denpasar. Ming Qu's research (2011) says that service quality is positively and significantly related to customer satisfaction

H1: Service Quality is significantly related to customer satisfaction

The influence of store image and satisfaction

This study showed Orth and Green research said that store image has a significant influence on loyalty. Agustin's research (2011) also stated that store image have positive and significant effect to customer satisfaction of Carrefour Surabaya.

$\mathrm{H} 2$ : Store image is significantly related to satisfaction 
The influence of service quality and loyalty

Aryani's research (2010) also finds that service quality is significantly influences with customer loyalty in KFC Jakarta. The results of Prayoga (2012) stated that the service quality has a significant effect on customer loyalty in his research at Ramayana Department Store

H3: Service quality is significantly related to loyalty

The influence of store image and loyalty

Dong-Mo-Ko (2003) states that store image has an influence on customer loyalty. In addition, according to Bloemer (1998) said the same thing that store image has an influence on customer loyalty. The statement is also supported by research conducted by Agustin (2011) which states that store image significantly influence customer loyalty Carrefour

H4: Store image is significantly related to loyalty

The influence of satisfaction and loyalty

In her research, Carpenter (2006) explains that satisfaction has a significant relationship with customer loyalty that research conducted on brand apparel. In the study Bowen (2001) said that customers should be made very satisfied to get customer loyalty. Normasari's research (2013) also found that customer satisfaction has a significant effect on customer loyalty

H5: Satisfaction is significantly related to loyalty

\section{METHOD}

This study uses 100 respondents by using purposive sampling is a technique of sampling. The respondents are customers who come shopping more than once a month. Methods of data collection in this study using questionnaires and interviews. This research use likert scale $1-4$. This study uses PLS to measure the data.

\section{DISCUSSION}

\section{Convergent Validity}

Outer loading is valid if the coefficient is between $0.60-0.70$ but theoretically outer loading 0.50 can still be recommended (Lathan and Ghozali,2012: 78), and significant at alpha level 0.05 or tstatistics 1.96. The following is the result of outer loading after the reconstruction model.

Table 1. Outer Loading value after reconstruction model

\begin{tabular}{lll}
\hline Indicator & Original Sample & T Statistic \\
\hline Reliability & 0.83 & 26.27 \\
Responsiveness & 0.87 & 26.48 \\
Assurances & 0.90 & 41.65 \\
Empathy & 0.85 & 25.33 \\
Store Atmosphere & 0.95 & 65.07 \\
Brand Diversity & 0.96 & 76.90 \\
Facilities & 0.64 & 8.48 \\
\hline
\end{tabular}




\begin{tabular}{lll}
\hline Quality Product & 0.92 & 42.28 \\
Price & 0.61 & 9.87 \\
Situational Factor & 0.92 & 42.99 \\
Personal Factor & 0.91 & 36.93 \\
WOM Positive & 0.90 & 34.42 \\
Repeat Purchase & 0.91 & 31.89 \\
Trust & 0.94 & 55.71 \\
Commitment & 0.88 & 26.04 \\
\hline
\end{tabular}

Table 1 shows that all outer loading values of construct measurement indicators have values> 0.60 and all indicators are significant at 0.05 , then in the next analysis used all indicators as listed in Table 1. In this table tangibles and location indicators are out because they have a value outer loading <0.60. Table 1 also explains that the value of outer loading of an indicator can also indicate the contribution rate of these indicators to other latent variables.

Table 1 shows that in the variable of service quality, reliability indicator gives a score of 0.83 , then followed by the responsiveness gives a score of 0.87 , assurance gives a score of 0.90 , and empathy gives a score of 0.85 .

There are 4 indicators in store image, but after reconstruction model there are 3 indicators giving each contribution as follows, store atmosphere indicator gives score 0,95 , then followed by indicator of brand diversity giving score 0,96 and facility indicator give a score of 0.64 .

For customer satisfaction variables have 4 indicators that contribute respectively as follows, the product quality indicator gives a score of 0.92 , the price indicator gives a score of 0.61 , situational factor indicator gives a score of 0.92 and personal factor indicator gives a score of 0.91

For customer loyalty variable has 4 indicator which give each contribution as follows, word of mouth positive indicator give score equal to 0,90 , followed by repeat purchase indicator giving score 0,91 , trust indicator give score equal to 0,94 and the indicator of commitment gives a score 0.88

Discriminant Validity

Table 2. Result of AVE and Correlation value between Dependent Variable

\begin{tabular}{llllll}
\hline \multicolumn{1}{c}{ Variable } & AVE & \multicolumn{1}{c}{ AVE } & Store Image & Satisfaction & ServQual \\
\hline Store Image & 0.74 & 0.86 & 1.00 & & \\
Satisfaction & 0.72 & 0.85 & 0.63 & 1.00 & \\
ServQual & 0.74 & 0.86 & 0.82 & 0.75 & 1.00 \\
Loyalty & 0.82 & 0.91 & 0.72 & 0.78 & 0.68 \\
\hline
\end{tabular}

In table 2 illustrates all values of Root AVE between 0.85-0.91. This value is greater than the correlation between variables, which are 0.63-0.82, and the AVE value of all variables above 0.50 . This value fulfills valid requirements based on discriminant validity criteria.

\section{Composite Reliability}

If the composite reliability and cronbach alpha has a value greater than 0.70 then the measurement is said to be reliable. Here are the results of composite reliability and cronbach alpha calculations. 
Table 3. Result of Composite Reliability and Cronbach Alpha

\begin{tabular}{lcc}
\hline \multicolumn{1}{c}{ Variable } & Composite & Cronbach \\
\hline Store Image & 0.89 & 0.83 \\
Satisfaction & 0.91 & 0.87 \\
ServQual & 0.92 & 0.89 \\
Loyalty & 0.95 & 0.93 \\
\hline
\end{tabular}

Based on Table 3 shows Cronbach Alpha's value indicates that all constructs are higher than 0.70 , which means that service quality variables, store image, customer satisfaction, and customer loyalty in this research model are reliable. Table 3 also shows that the composite reliability value of all constructs has a value greater than 0.70 so that it meets reliable requirements based on composite reliability criteria.

\section{$R$ Square}

According to Chin (Lathan and Ghozali, 2012: 85), the R-Square (R2) of 0.67 is a strong model, R-Square (R2) is 0.33 moderate, and R-Square (R2) is 0,19 is a weak model. Here is a calculation of R-Square can be seen in the following table.

Table 4. Structural Inner

\begin{tabular}{ll}
\hline Organoleptic & R Square \\
\hline $\begin{array}{l}\text { Store Image } \\
\text { Satisfaction }\end{array}$ & 0.57 \\
$\begin{array}{l}\text { ServQual } \\
\text { Loyalty }\end{array}$ & 0.71 \\
\hline
\end{tabular}

Table 4 shows that the value of customer satisfaction R2 is 0.5 . Based on the criteria of Chin (Lathan and Ghozali, 2012: 85), the model includes strongly approaching model criteria. In other words, variation of customer satisfaction can be explained by the variation of service quality and store image by $5 \%$. The remaining $43 \%$ is explained by variations of other variables. Meanwhile, customer loyalty has an R-square value of 0.71 or including a strong model, meaning the variation of service quality, store image and customer satisfaction can explain the variation of customer loyalty that is equal to 71 percent of the remaining 29 percent explained by the variation of other constructs outside the model.

\section{$Q$-Square Predictive Relevance $\left(Q^{2}\right)$}

The calculation about Q-Square is $1-(1-\mathrm{R} 12)(1-\mathrm{R} 22))=1-(1-0.57)(1-0.71)=1-0.12$ $=0.88$, that is meaning 88 percent of variations in endogenous constructs can be predicted by variations in exogenous constructs

\section{Goodness of Fit}

Based on strong and weak criteria, GoF (Lathan and Ghozali, 2012: 88) are as follows: 0.36 (GoF large), 0.25 (GoF medium), and 0.10 (GoF small).). Here is a calculation of the goodness of fit can be seen in the following table. 
Table 5. Goodness of Fit

\begin{tabular}{lcc}
\hline \multicolumn{1}{c}{ Variable } & R Square & Communality \\
\hline Store Image & & 0.74 \\
Satisfaction & 0.57 & 0.72 \\
ServQual & & 0.74 \\
Loyalty & 0.71 & 0.82 \\
Means & 0.64 & 0.76 \\
\hline
\end{tabular}

In table 5 the GoF shows a value of $\sqrt{ } \mathrm{AR} 2 *$ A.Com $=\sqrt{ } 0.64 * 0.76=0.70$. Conclusion about this value means the GoF of this study is good model criteria (large).

Path Analysis

In the following table will explain the path analysis

Table 6. Path Analysis

\begin{tabular}{llll}
\hline Variable & Original Sample & T Statistic & Result \\
\hline Store Image > Satisfaction & 0.13 & 0.99 & Not Significant \\
Store Image > Loyalty & 0.44 & 3.31 & Significant \\
Satisfaction > Loyalty & 0.59 & 5.38 & Significant \\
Serv. Qual. > Satisfaction & 0.63 & 5.73 & Significant \\
Serv. Qual. > Loyalty & -0.13 & 0.93 & Not Significant \\
\hline
\end{tabular}

Based on Table 6, it can be described the test results between variables as follows

\section{Results from the influence of service quality with satisfaction}

The result of influence of service quality to customer satisfaction showed that service quality had positive effect 0,63 to customer satisfaction and significant with $t$ statistic 5,73. The results of this test prove that hypothesis 1 states that the quality of service has a positive and significant relationship on customer satisfaction is acceptable. Based on result of hypothesis test of influence of service quality to customer satisfaction, showing where service quality has significant effect to customer satisfaction. If the company provides good service, quality will increase customer satisfaction besides that it can also have a good impact on the company.

\section{Results from the influence of store image with satisfaction}

Test result about the relationship of store image to customer satisfaction shows that store image have positive effect 0,13 to customer satisfaction, but the score is not significant at level 0,05 , because t-statistic value less than 1.96 that is equal to 0,99 . The results of this test prove that hypothesis 2 which states that store image has a significant relationship on customer satisfaction is not acceptable.

Based on test result about influence of store image to customer satisfaction where store image have positive but not significant to customer satisfaction. This implies that the better the image of the store will have an impact on customer satisfaction, but the increase is not significant. The results of this study indicate that the cause of the insignificant results of research because the indicators of store atmosphere, the brand diversity and facilities are below the average variables of 
the store image, especially the facility indicators are very far below the average variable store image

Results from the influence of service quality with loyalty

Test results about the relationship of service quality on customer loyalty showed the service quality had negative effect of -0.13 to customer loyalty and the relationship was not significant at 0,05 with value of $t$ equal to 0,93 . The results of this test proves that hypothesis 3 which states that the service quality significant relationship on customer loyalty is not acceptable.

The results of this study can explain the better service quality is not provided always able to make customers become loyal because the service quality must be through customer satisfaction in advance to make customers become loyal. Another cause is the assurance indicators and tangibles that are below the average service quality. Assurance indicators with an average score of 3.40 slightly below the average score of service quality variables with an average grade of 3.42 . However, tangibles that have an average score of 3.16 are far below the average value of service quality variables with a value of 3.42 .

Results from the influence of store image with loyalty

The result of relationship of store image to customer loyalty shows that store image has a positive relationship of 0.44 on customer loyalty, and the relation is significant with $t$ value equal to $3,31>1,96$. These results prove that hypothesis 4 which states that store image has a significant effect on loyalty is acceptable. Based on the test results about the relationship of store image to customer loyalty shows where the image store significant effect on loyalty.

These results show that the better the company maintains its image will have an impact on loyal customers in the company. The location indicator that has an average score of 3.92 is well above the average score of 3.49 score which also indicates that the location indicator is an important asset owned by the company. This strategic location can make it easier for customers to promote the company by word of mouth and allows prospective customers to find companies that have a strategic location. Store atmosphere with a slightly below average score of 3.47 also plays an important role to display a good image for customers, by displaying a good store display arranged according to the type of goods and given directions on where the item can be found. By doing that can make it easier for customers to find the desired goods and facilitate the work of employees, while the atmosphere of a comfortable and clean store can also generate a good image of the customer

Results from the influence of satisfaction with loyalty

Test results about the relationship of satisfaction on loyalty showed that the satisfaction of significant remote with a value of 0.59 and the value of $t$ statistics of 5.38. This result proves that hypothesis 5 which say the satisfaction has a significant relationship to loyalty is acceptable.

Based on the test results about the influence of satisfaction on loyalty, showing where satisfaction has a significant effect on loyalty. These results give meaning that the more satisfied customers it would have a very good impact on loyalty. 


\section{The Role of Mediation Customer satisfaction}

Direct relationship between service quality to customer loyalty is equal to -0.13 with value $t$ statistic 0.99 therefore the relationship is not significant, while the relationship between service quality to customer satisfaction equal to 0.63 with t statistic value 5.73 hence relationship is significant. On the other hand the relationship of customer satisfaction as a mediation between customer quality to customer loyalty of 0,59 with $t$ statistic value 5.38 hence the relationship is significant. This is meaning customer satisfaction is the full mediation between service quality and loyalty.

Direct relationship between store image to customer loyalty is equal to 0.44 with value $\mathrm{t}$ statistic 3.31 hence the relationship is significant, while direct relation between store image to customer satisfaction equal to 0,13 with value $\mathrm{t}$ statistic 0.99 hence the relationship is not significant. On the other hand the relationship of customer satisfaction to customer loyalty is 0,59 with t statistic value 5.38 hence the relationship is significant. this is meaning customer satisfaction is not a mediation between store image and loyalty

\section{CONCLUSION, LIMITATION AND IMPLICATION}

\section{Conclusion}

Service quality plays a very important role in customer satisfaction. Employees must be trained in order to have good reliability. They have work fast and are responsive in meeting customer demand, in addition, employees must also have a high empathy to their customers, employees must also be provided by the science of retail and service as a guarantee that the employee is superior in the field, and must provide tangibles as evidence to the customer. In this case tangibles should be addressed as employees should be well dressed, providing the appearance of equipment and facilities that can function properly.

Store image is an important element to improve customer loyalty, there are several points that can be utilized is a very strategic location, easy to find plus a large parking area is a very good capital. Increase the convenience of the atmosphere of the store atmosphere so there is a sense of fun and comfortable in shopping so that it can generate interest to come back, store displays should also be considered for all goods on the premises should be, this also can facilitate the work of employees

\section{Limitation and Implication}

Based on data analysis and research results described above, the implications of this research are the theoretical implications and practical implications. In theoretical implications, the results of this study contribute as the development of science, insight and reference for subsequent researchers that the service quality has not significant with customer loyalty and store image has not significant on customer satisfaction in this study. This study also confirmed that customer satisfaction has a significant relationship on customer loyalty.

The practical implications of this study, the company should examine the policies that can be associated with the finding that the service quality has an important role to improve customer satisfaction and store image that have a good impact on customer loyalty. The company should also provide better tangibles to its customers with improved facilities so that they can keep pace with current technology developments. Price competition among the closest competitor should 
also be considered and marketing with word of mouth positive can be used as a free promotion for the company.

The study only use four variables are service need to add another variable like repeat purchase, word of mouth positive, trust, marketing mix or other related variables. Next study need separated about perception man and woman to know about who is more satisfied between man and woman in store service.

\section{Acknowledgement.}

I would first express my greatest gratitude to the organizing committee of the International Conference on Social Sciences (ICOSS) of Universitas Warmadewa for the great contribution that has been granted to the launching of this scientific script at EAI Publisher. I hope that the ideas found in the paper can be additional to the theoretical and practical konwledge for many parties.

\section{REFERENCES}

[1]. Agustin, Budiyanto dan Ridwan. 2012. Kepuasan Pelanggan memediasi hubungan Store Image dan Ekspektasi Pelanggan terhadap Loyalitas Pelanggan. Jurnal Sekolah Tinggi Ilmu Ekonomi Indonesia Surabaya Volume 15

[2]. Bloemer, J. and Odekerken-Schröder, G. (2002). Store satisfaction and store loyalty explained by customer- and store-related factors. Journal of Consumer Satisfaction, Dissatisfaction and Complaining Behavior, 15, 68-80

[3]. Bowen, John T \& Shiang-Lih Chen.2001. The Relationship Between Customer Loyalty and Customer Satisfaction, Vol. 13

[4]. Carpenter. 2006. Consumer shopping value, satisfaction, and loyalty for retail apparel brands. Journal of Fashion Marketing and Management Vol. 9 No. 3

[5]. Chang, Chih-Hon and Chia-Yu Tu. 2005. Exploring Store Image, Customer Satisfaction and Customer Loyalty Relationship: Evidence from Taiwanese Hypermarket Industry. The Journal of American Academy of Business, Cambridge Vol.7. Num.2. September

[6]. Chodzaza and Gombachika. 2013. Service Quality, Customer Satisfaction and Loyalty among Industrial Customer of Public electricity in Malawi. International journal of energy sector management vol 7 no 2.

[7]. Do Mong Ko. 2003. Inter-Relationship among Store Image, Store Satisfaction and Store Loyality among Korea discount retail patrons. Asia Pasific Journal of marketing logistic. ABI logal, 15, 42-71

[8]. Ghozali.2014. Pengaruh Kualitas Pelayanan dan Harga terhadap Kepuasan Pelanggan pada Expedisi di Surabaya. Jurnal Ilmu \& Riset Manajemen Vol. 3 No. 3

[9]. Kottler dan Keller. 2009. Managemen Pemasaran Bagian 5 - 8. Jakarta. Erlangga

[10]. Lovelock, C.H dan Wright, L.K. 2007. Manajemen Pemasaran Jasa. Edisi Bahasa Indonesia. Jakarta: PT Indeks.

[11]. Mowen, J.c, Minor. 1998. Customer behavior. 5th ed. Upper Sadle River, NJ Pretince Hall inc

[12]. Mellisa. 2010. Pengaruh pelayanan ritel dan citra toko terhadap kepuasan pelanggan dan loyalitas pelanggan. Thesis. Universitas Udayana

[13]. Ming Qu dkk. 2011. Relationships among customer loyalty programs, service quality, relationship quality and loyalty. Chinese Management Studies Vol. 5 No. 2, 
[14]. Prayoga.2013. Pengaruh Kualitas Pelayanan terhadap Kepuasan dan Loyalitas Pelanggan pada Ramayana Departmen Store di Kota Denpasar. Fakultas Ekonomi dan Bisnis Universitas Udayana (Unud), Bali, Indonesia

[15]. Sangadji dan Sopiah. 2013. Perilaku Konsumen. Yogyakarta. Andi offset

[16]. Singh, H. 2006. The Importance of Customer Satisfaction in Relation to Customer Loyalty and Retention, Asia Pacific University College of Technology \& Innovation Technology Park Malaysia, UCTI Working Paper

[17]. Tjiptono. 2014. Pemasaran Jasa. Yogyakarta. Andi Offset

[18]. Tjiptono dan Chandra. 2016. Service Quality and Satisfaction. Yogyakarta. Andi offset

[19]. Zeithaml dan Britner. 1996. Service Marketing: Integrating customers focus Across the
firm.
First
edition.
USA.
McGrawhill
Com 